Journal of Business and Management Studies (JBMS)

ISSN: 2709-0876

DOI: 10.32996/jbms

Journal Homepage: www.al-kindipublisher.com/index.php/jbms

\title{
Packaging Attributes and Consumer Patronage of Cosmetics in Calabar Metropolis, Cross River State
}

\author{
Ezekiel Tom Ebitu ${ }^{1}$ (D) , Samuel Etuk ${ }^{2}$ (D) $ه$, Joy Ekoi Ofem ${ }^{3}$ (D) and Olom, Patricia Akwaya ${ }^{4}$ (D) \\ ${ }^{1}$ Professor, Department of Marketing, University of Calabar, Nigeria \\ ${ }^{2}$ Senior Lecturer, Department of Marketing, University of Uyo, Nigeria \\ ${ }^{3}$ PhD Student, Department of Marketing, University of Calabar, Nigeria \\ ${ }^{4}$ Lecturer, Department of Vocational Education, University of Calabar
}

$\triangle$ Corresponding Author: Samuel Etuk, E-mail: asametuk@uniuyo.edu.ng

ARTICLE INFORMATION ABSTRACT

Received: February 08, 2021

Accepted: April 18, 2021

Volume: 3

Issue: 1

DOI: $10.32996 / j b m s .2021 .3 .1 .4$

\section{KEYWORDS}

Packaging Attributes, Consumer

Patronage, Cosmetics, Brand

Name, Packaging Information,

Design of Wrapper
The research examined packaging attributes and consumer patronage of cosmetics in Calabar Metropolis, Cross River State. It was conducted to determine how packaging attributes influenced consumer patronage of cosmetic products in Calabar Metropolis. The study specifically explored the effect of brand name, packaging information and design of packaging wrapper on consumer patronage of cosmetics in Calabar Metropolis, Cross River State. Cross sectional survey research design was adopted and primary data were collected from 139 cosmetic consumers in Calabar Metropolis using structured questionnaire. The data collected were analyzed using multiple linear regression in the Statistical Package for the Social Sciences (SPSS 23). The findings revealed that brand name, packaging information and design of packaging wrapper had a significant effect on consumer patronage of cosmetics in Calabar Metropolis, Cross River State. Hence, it was concluded that packaging attributes had a significant effect on consumer patronage of cosmetics in Calabar Metropolis, Cross River State. Therefore, the following recommendations were made: manufacturers of cosmetics in Calabar should strive to build strong brand names for their products by maintaining the highest level of product quality in order to enhance consumer patronage; adequate product information should be displayed on the packaging of cosmetics in order to enable consumers make informed purchase decisions; , and manufacturers of cosmetics in Calabar should consistently ensure that attractive designs are displayed on the packaging of their products in order to entice consumers to patronize.

\section{Introduction}

Nigeria is a huge market for cosmetic products and plays host to some of the most prominent cosmetic dealers and brands in the world. As of 2018, the Nigerian cosmetics industry was worth an estimated market value of N500 billion annually (Okereocha, 2018), and given the country's large female population, the industry is projected to grow larger over the next several years. Cosmetic manufacturers, dealers and marketers have taken advantage of this situation as an economic opportunity to produce and market cosmetics to Nigerian consumers. Given the market value and potential of the industry, cosmetics manufacturers and marketers vigorously compete with each other to gain market share using various marketing strategies and programmes including packaging. Packaging is the process of designing and producing containers and wrappers for products (Keller, 2009). It is so important that most marketers believe it is the fifth " $\mathrm{P}$ " of the marketing mix (Ebitu, 2019) and it is considered to be an important element in product strategy. Packaging is an important factor of brand recognition as well as an important factor in creating positive brand associations. In competitive industries, like the cosmetics industry, packaging can be an effective way of achieving marketing objectives and satisfying consumers' desires through aesthetic elements like package size, shape, text,

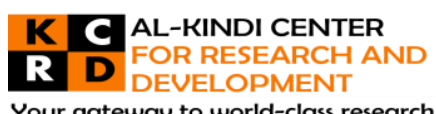

Your gateway to world-class research

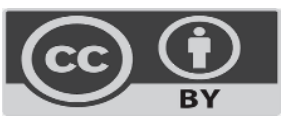

Published by Al-Kindi Center for Research and Development. Copyright (c) the author(s). This open access article is distributed under a Creative Commons Attribution (CC-BY) 4.0 license 
colour, material and graphics and its functional elements as well (Rundh, 2005). Similarly, Robert (2011) maintains that packaging plays essential roles in marketing such as protecting products; enabling product storage, facilitating product transportation to end consumers; enabling consumers to safely handle products while preserving their quality; and promoting products by persuading consumers to buy the products through innovative and creative display of graphics. As such, manufacturers and dealers of cosmetic products have significantly intensified their use of packaging as an important tool for marketing their products.

The practice of packaging is dominantly visible in the Nigerian cosmetics and beauty products industry. Virtually all cosmetic products in Nigeria have their unique packaging enabling consumers to identify and differentiate them from similar products. Manufacturers and dealers of cosmetic products use packaging attributes (such as brand name, information, design of wrapper, among others) as a tool for product differentiation and promotion in order to gain consumers' awareness and patronage. Brand name is the unique identity of a brand; it is a part of the brand that can be vocalized and it is a distinct name by which a product is known to the target audience. Every brand has a name because it helps to identify the brand at a glance and differentiate it from competing brands (Ibrahim, Abdullahi \& Bello, 2019). Similarly, Ghosh (2016) presents packaging information as the information displayed on or in the package of a product describing the product; its composition, key ingredients, manufacturer/distributors, country of origin, manufacture/expiry dates, means of usage and precautions. On the other hand, design of packaging wrapper is the way a packaging material is designed; and it includes the aesthetic, graphical and artistic elements that appear on a product's package. Graphical and artistic designs on packaging make a brand unique, preserve its individuality, and enable the brand to stand out on the shelf. Packaging design adds value to the physical appearance of a brand and increases its aesthetic quality (Imiru, 2017).

Applied to the Nigerian cosmetics and beauty products industry, manufacturers and dealers of cosmetic products use alluring and attractive colours for packaging their products so as to easily catch the attention of consumers and entice them to patronize. Persuasive and comprehensive information is also displayed on or in the packaging of cosmetic products in order to transfer product knowledge to consumers. Similarly, attractive graphical and artistic designs are displayed on the packaging of cosmetic products in order to gain consumers' awareness, patronage and repeat patronage. Against this backdrop, this study examined the effect of packaging attributes on consumer patronage of cosmetics in Calabar Metropolis, Cross River State.

\subsection{Statement of the problem}

The subject "Packaging attributes and consumer patronage" has received a great deal of research attention among researchers in Nigeria. Researchers such as Owolabi and Isaac (2009) in Oyo State; Ishaku and Tijani (2013) in Taraba State; Orji (2014) in Abia State; Adebisi and Akinruwa (2019) in Ekiti State; and Oladele, Olowookere, Okolugbo and Adegbola (2015) in Ekiti State, have lent ample research attention to the subject over the years. On the subject of packaging, most researchers have limited the scope of their studies to various consumer products such as agro-processed food products, beverage drinks, bread, Bournvita and toothpaste, among others. However, none of these studies focused on cosmetics products in Calabar, Cross River State. This reveals a subject and geographical gap in literature concerning packaging and consumer patronage. In a bid to close these gaps, this study examined packaging attributes (brand name, information and design of packaging material) and consumer patronage of cosmetics with particular emphasis on Calabar Metropolis in Cross River State, Nigeria. This led to the formulation of the following specific objectives:

1. To examine the effect of brand name on consumer patronage of cosmetics in Calabar Metropolis, Cross River State.

2. To ascertain the effect of packaging information on consumer patronage of cosmetics in Calabar Metropolis, Cross River State.

3. To determine the effect of design of packaging wrapper on consumer patronage of cosmetics in Calabar Metropolis, Cross River State.

\section{Review of Related Literature}

\subsection{Theoretical framework}

This study is based on the Bradley Carter's classical theory of packaging developed by Bradley Carter in 1991 and the hierarchy of effects model developed by Lavidge and Steiner in 1961. The basic assumption of the Bradley Carter's classical theory of packaging is that product packaging is the most important stimulus of consumer buying behaviour towards consumer goods. Product packaging is the most important factor that stimulates consumers to notice, evaluate, select and ultimately purchase a consumer good. According to the theory, there are three (3) elements in the relationship between consumer behavior and packaging, these are: The actor, stimulus and subject. The actor is the consumer himself going through the various stages of consumer decision-making. The actor (consumer) is considered rational in his decisions and will select the product option that best appeals to his preferences. The stimulus is product packaging, which includes elements like colour, design of wrapper, quality of packaging material, brand name and packaging information. Packaging colour entails the color combinations used to 
design the packaging of consumer products. Design of wrapper entails the graphic and visual designs that appear on the packaging of consumer products. Quality of packaging material entails the texture or nature of the material used to design the packaging of consumer products. Brand name is the formal identity of a brand by which consumers can recognize it, while packaging information entails the amount of product-related and other essential information displayed on the packaging of consumer products. Finally, the subject, as the name implies, is the consumer product itself which the consumer is being exposed to. According to the classical theory of packaging, the actor (consumer) is influenced to purchase and use the subject (product) by the stimulus (product packaging). The effect of the stimulus (packaging) on the player (consumer) is amplified when the stimulus (packaging) has the right colour combination, recognizable brand name, attractive graphic and visual designs, highquality packaging material and adequate and accurate product-related information. In the classical theory of packaging, much focus is not put on the subject (consumer product) as a determinant of consumer buying behaviour because it is believed that that the stimulus (product packaging) is the most important influencer of consumer buying behavior.

The hierarchy of effects model was created in 1961 by Robert J. Lavidge and Gary A. Steiner. This marketing model states that consumers go through six (6) steps when viewing a company's advertisements, hence the job of the advertiser is to encourage the consumer to go through the six steps and purchase the products. The six (6) steps are as follows:

(a) Awareness: The consumer becomes aware of the product through advertising. This is a challenging step because there is no guarantee that the consumer will be aware of the product/brand after they view the advert. Consumers see many adverts each day but will only remember the brand of a tiny fraction of products.

(b) Knowledge: The consumer begins to gain knowledge about the product, for example through the internet, retail stores and product packaging. In today's digital world, this step has become more important as consumers expect to gather product knowledge at the click of a button. Consumers will quickly move to competitors' brands if they do not get the information they need. The advertiser's job is to ensure product information is easily available and accessible.

(c) Liking: As the title states, this step is about ensuring that the consumers like the product. As an advertiser, the urgent task is to promote the distinctive and unique product features and capabilities to encourage consumers to like the product.

(d) Preference: Customers may like more than one product brand and could end up buying any one of them. At this stage, advertisers will want the consumers to disconnect from rival brands and focus on their particular brands. Advertisers will want to highlight their brands' benefits and unique selling points so that the consumers can differentiate it from competing brands.

(e) Conviction: This stage is about creating the consumer's desire to purchase the product. Advertisers may encourage conviction by allowing consumers to test or sample the product. Examples of this are inviting consumers to take a car for a testdrive or offering consumers a free sample of a food product. This reassures consumers that the purchase will be a safe one.

(f) Purchase: Having proceeded through the above stages, the advertiser wants the consumer to purchase his products. This stage needs to be kept simple and easy. Otherwise, the consumer will get fed up and walk away without any purchase. For example, a variety of payment options encourages purchase, while a complicated and slow website discourages purchase.

The relevance of the Bradley Carter's classical theory of packaging to this study is that product packaging is one of the important stimuli of consumer buying behaviour towards cosmetics in Calabar. According to the theory, cosmetics packaging is one of the most important factors that stimulate consumers to notice, evaluate, select and ultimately purchase these products. The theory maintains that the relationship between packaging and consumer patronage of cosmetics includes three (3) elements, namely: the consumer (actor), product packaging (stimulus) and cosmetics (subject). According to the theory, consumers of cosmetics in Calabar (actor) are influenced to purchase and use cosmetics (subject) by product packaging (stimulus). The effect of product packaging (stimulus) on consumers (actor) is amplified when the product packaging (stimulus) has a recognizable brand name, attractive graphic and visual designs, high quality packaging material and adequate and accurate product-related information. Similarly, the implication of the hierarchy of effects model to this study is that product packaging, like advertising, is a useful marketing tool used by manufacturers and dealers of cosmetics to communicate information about the products to consumers in an attempt to gain consumer patronage and loyalty. Using distinctive brand names, colour combinations, information and design of wrapper, the packaging of cosmetics serves as a promotional tool intended to attract and entice patronage by target consumers. The model assumes that consumers pass through six (6) stages in their minds when exposed to the packaging of cosmetics. These stages include: awareness, knowledge, liking, preference, conviction and purchase.

\subsection{Conceptual framework}

Packaging refers to the process of designing the package such as containers, wrappers etc. It plays a very significant role in the marketing success or failure of products especially for non-durable consumer products (Kalpana, 2019). According to Kalpana (2019), the package is the wrapping material around a product that serves to contain, identify, describe, protect, display, promote and otherwise make the product marketable and keep it clean. According to the author, it not only provides protection for the product but also acts as a promotional tool. Sometimes, consumers assess the quality of the product from its packaging. 
The author asserts that packaging has been described as a silent salesman and it has played an important role in the success of many products like Colgate Toothpaste, Taj Mahal Tea, Lays Wafers etc.

In the view of Kamiah (2017), packaging is the activity of designing and producing the container or wrapper for the product. It is an important and effective sales tool for encouraging consumers to buy a firm's products. In the author's view, it is a powerful medium for sales promotion and it must perform the following basic functions: protection, ease of handling and storage, convenience in usage etc. and should not be deceptive and convey any deceptive message. The author asserts that it is the best method for attracting consumers to buy products. Garrison (2019) observes that packaging refers to all those activities related to designing, evaluating and producing the container for a product. Simply, the box-like container, wherein the product is stored to protect it from any physical damage and at the same time attracting the customer through its appeal is called as packaging. The author explains that a product might have three layers of packaging, such as, a toothpaste which comes in the plastic tube (primary package), then it is packed in a cardboard box (secondary package) and finally, it is packed in a corrugated box (shipping or third package).

Mauricio (2015) views packaging as the physical appearance of a product when a consumer sees it. With the increased importance placed on self-service marketing, the author observes that the role of packaging is becoming quite significant. For example, in a typical supermarket a shopper passes about 600 items per minute, or one item every tenth of a second. Thus, the only way to get some consumers to notice the product is through displays, shelf hangers, tear-off coupon blocks, other point-ofpurchase devices, and, last but not least, effective packages. Considering the importance placed on the package, the author argues that it is not surprising that a great deal of research is spent on motivational research, color testing, psychological manipulation, and so forth, in order to ascertain how the majority of consumers will react to a new package. Furthermore, the author maintains that based on the results of this research, past experience, and the current and anticipated decisions of competitors, the marketer will initially determine the primary role of the package relative to the product and decide whether it should include quality, safety, distinction, affordability, convenience, or aesthetic beauty.

Furthermore Garrison (2019) asserts that in today's world, packaging is not limited to the protection of a product alone; it has been used as a marketing tool for building brand equity and boosting sales. On that basis, the author argues that most companies use packaging as an important marketing tool because of the following factors:

(a) Packaging enables self-service, as in the case of purchases done in the supermarkets and retail mart the customers select the products on their own without any assistance from the retailers. Thus, a company must design its product package in such a way that it is capable to draw customer's attention towards it.

(b) It helps in increasing consumer affluence, which means that customers are willing to pay even more for the convenience, appearance, dependability of better packages.

(c) Packaging helps in increasing brand recognition among customers. As soon as customers see the package, they can instantly relate it to the company or brand. Thus, packaging can influence buyers to initiate purchase actions since buyers come in contact with a product's package first before the product itself.

Also, according to Kalpana (2019), the following are the three levels of packaging:

(a) Primary package: Primary package refers to the product's immediate package. In certain cases, such package is retained till the consumer is ready to use the product. For example, plastic packet for socks while in some other cases such package is used throughout the life of the product such as the bottle carrying jam or tomato sauce etc.

(b) Secondary packaging: Secondary packaging is the additional packing given to a product to protect it. Such packing is retained till the consumer wants to start using the product. For example, some soaps usually come in a card-board box. The consumer first throws the box when he desires to use it and then discards the plastic wrapper too to get hold of the soap.

(c) Transportation packaging: It refers to packages essential for storing, identifying or transporting products. For example, the use of corrugated boxes, wooden crates etc., while transporting products.

Similarly, Mauricio (2015) presents the following as the important roles of product packaging:

(a) Physical protection: The objects enclosed in the package may require protection from mechanical shock, vibration, electrostatic discharge, compression, temperature, etc. 
(b) Information transmission: Packages and labels communicate how to use, transport, recycle, or dispose of the package or product. With pharmaceuticals, food, medical, and chemical products, some types of information is required by governments. Some packages and labels also are used for track and trace purposes.

(c) Marketing: Packaging and labels can be used by marketers to encourage potential buyers to purchase the product. Package graphic design and physical design have been important and constantly evolving phenomenon for several decades. Marketing communications and graphic design are applied to the surface of the package and (in many cases) the point of sale display.

(d) Convenience: Packages can have features that add convenience in distribution, handling, stacking, display, sale, opening, reclosing, use, dispensing, reuse, recycling, and ease of disposal.

(e) Barrier protection: A barrier from oxygen, water vapor, dust, etc., is often required. Permeation is a critical factor in design. Some packages contain desiccants or oxygen absorbency to help extend shelf life. Modified atmospheres or controlled atmospheres are also maintained in some food packages. Keeping the contents clean, fresh, sterile and safe for the intended shelf life is a primary function.

(f) Security: Packaging can play an important role in reducing the security risks of shipment. Packages can be made with improved tamper resistance to deter tampering and also can have tamper-evident features to help indicate tampering. Packages can be engineered to help reduce the risks of product pilferage.

\subsection{Empirical review}

Orji (2014) conducted a study on "Packaging attributes and consumer purchase behaviour towards bread products in Abia State." The objective of the study was to determine the effect of packaging attributes on consumer purchase behaviour towards bread products in Umuahia, Abia State, Nigeria. Primary data were collected from a sample of 395 respondents through a structured questionnaire. Data analysis was done using descriptive statistics in the Statistical Package for the Social Sciences (SPSS). The findings of the study revealed that all nine packaging elements tested (packaging color, labeling, quality of packaging material, design of wrapper, printed information, language, brand image, innovation/practicality, and quality of packaging) had significant positive effects on consumer purchase behaviour towards bread products in Umuahia, Abia State. On the basis of these findings, the study concluded that packaging attributes had a significant positive effect on consumer purchase behaviour towards bread products in Abia State.

Adebisi and Akinruwa (2019) investigated the "Effectiveness of product packaging on consumer patronage of Bournvita in Ekiti State." The study was aimed at examining the effectiveness of product packaging on consumer patronage. Primary data were collected using a structured questionnaire from a sample of 322 respondents. Collected data were analyzed using descriptive statistics and hierarchical multiple regression. The results showed that all the tested variables (size, colour, package material, product content and shape of product) have significant positive effects on consumer patronage of Bournvita. It was concluded that consumers' decision to patronize could be influenced by taking into consideration size, colour, package material, product content and shape of a product. Based on these findings, it is recommended that producing different sizes of the product should be a continuous practice that firms should undertake. Moreover, producers should consciously adopt colours suitable and capable of appealing to consumers' interest and consequently influence their choice of products by mere sighting of the package colour.

Similarly, Ibrahim, Abdullahi and Bello (2019) examined the "Impact of packaging on consumer buying behaviour in Nasarawa State". The study was focused on determining the impact of packaging elements (brand name, packaging information, design of wrapper, and packaging colour) on consumer buying behaviour towards detergents in Nasarawa State, Nigeria. Primary data were collected from 128 respondents in Nasarawa State using Likert scale questionnaire. Data analysis was done using Ordinary Least Square (OLS) regression method. Subsequently, it was found that brand name, packaging information, design of wrapper, and packaging colour had significant direct impacts on consumer buying behaviour towards detergents in Nasarawa State, Nigeria. Hence, the study concluded that packaging had a significant direct impact on consumer buying behaviour towards detergents in Nasarawa State, Nigeria. Based on the forgoing, the study recommended that there is need for organizations to concentrate their efforts on making the packaging of their products very attractive in order to attract and retain the interest of consumers.

Also, Ismaila, Tanko and Halilu (2017) conducted a study on the "Effect of product packaging on Nigerian consumers' behaviour in Adamawa State". The study had the specific objective of ascertaining the effect of packaging colour, packaging size, brand name, design of wrapper, and quality of packaging material on Nigerian consumers' behaviour in Adamawa State. Structured questionnaire copies were administered to collect primary data from 222 respondents in Adamawa State. Pearson Product Moment Correlation in the Statistical Package for the Social Sciences (SPSS 21.0) was adopted to analyze the data collected. The findings revealed that packaging colour, packaging size, brand name, design of wrapper, and quality of packaging material had significant positive effects on Nigerian consumers' behaviour in Adamawa State. Therefore, the study concluded that product 
packaging had a significant positive effect on packaging colour, packaging size, brand name, design of wrapper, and quality of packaging material on Nigerian consumers' behaviour in Adamawa State. On the basis of this conclusion, the study recommended that marketers should know and understand the importance of product packaging because of its benefits as Nigerian consumers consider the packaging of products at the time of purchase.

Mzwella and Saviour (2018) conducted a study on "Impact of packaging elements on consumer buying behaviour of fast-moving consumer goods (FMCGs) during the hyperinflationary and after the dollarization eras in Zimbabwe". The study was initiated to investigate the impact of packaging elements (packaging information, packaging size, design of wrapper, and background image) on consumer buying behaviour towards fast-moving consumer goods (FMCGs) during and after the multi-currency period in Zimbabwe. Primary data were elicited from a sample of 79 respondents from the retail sector in Harare using a combination of interview and questionnaire methods. The data were analyzed using multiple regression in the Statistical Package for the Social Sciences (SPSS 22.0). The findings revealed that packaging information, packaging size, design of wrapper, and background image had a significant impact on consumer buying behaviour towards fast-moving consumer goods (FMCGs) during and after the multi-currency period in Zimbabwe. Therefore, the study concluded that there was a significant impact of packaging elements on consumer buying behaviour of fast-moving consumer goods (FMCGs) during the hyperinflationary and after the dollarization eras in Zimbabwe. Extensive literature review and discussion facilitated the development of the study's conceptual framework, as presented in Figure 1. The conceptual model is constituted by the three null hypotheses as follows:

1. Brand name has no significant effect on consumer patronage of cosmetics in Calabar Metropolis, Cross River State.

2. Packaging information has no significant effect on consumer patronage of cosmetics in Calabar Metropolis, Cross River State.

3. Design of packaging wrapper has no significant effect on consumer patronage of cosmetics in Calabar Metropolis, Cross River State

\section{Methodology}

Cross-sectional survey research design has been adopted for the study, which was conducted in Calabar, the Capital of Cross River State in Nigeria. The target population included all female residents in Calabar South and Calabar Municipality as of 2019. Using the Topman formula, a sample size of 177 cosmetics users was statistically determined. The sample elements were drawn with the aid of a cluster random sampling technique. A structured questionnaire was administered to obtain primary data from cosmetics users in Calabar Metropolis. The instrument measured respondents' opinions on a five-point Likert scale. Its validity status was confirmed through authority-vetting method, while its reliability status was confirmed through the Cronbach alpha reliability procedure. The Cronbach's alpha score for the four constructs are: Brand name $=0.866$, Packaging information $=$ 0.791 , Design of packaging wrapper $=0.744$, and Consumer patronage $=0.827$. Data analysis was done using inferential statistics (multiple linear regression) in order to determine the individual contributions or effects of each packaging attribute on the dependent variable (consumer patronage), thereby demonstrating the cause-and-effect relationship between the study variables. This analysis was computed electronically with the aid of the Statistical Package for Social Science (SPSS 23).

Figure 1: Conceptual model of the relationship between packaging attributes and consumer patronage of cosmetic products

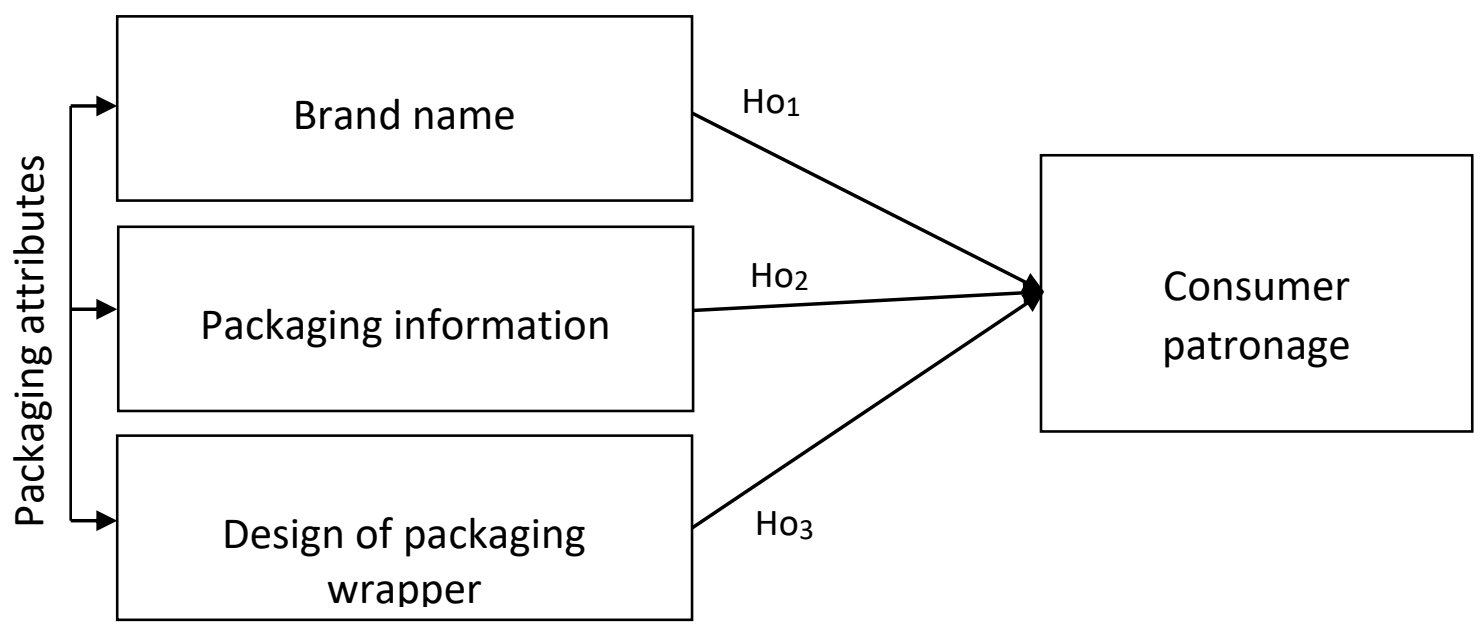

Source: Researcher's model 


\section{Results and Discussion}

A total of 177 copies of the questionnaire were administered to female residents in Calabar South and Calabar Municipality. Out of the 177 questionnaire copies distributed, 139 copies representing 78.5 percent were correctly completed and returned, while 38 copies representing 21.5 percent were not returned, therefore resulting in a total response rate of 78.5 percent.

\subsection{Result of research hypotheses}

Table 1: Summary of respondents' demographic characteristics

\begin{tabular}{|lll|}
\hline Marital status & Frequency & Percent \\
Single & 79 & 56.8 \\
Married & 44 & 31.7 \\
Divorced & 16 & 11.5 \\
Total & 139 & 100.0 \\
& & \\
Age & & \\
$18-24$ years & 60 & 43.2 \\
$25-31$ years & 17 & 12.2 \\
$32-38$ years & 18 & 12.9 \\
$39-45$ years & 20 & 14.4 \\
46 years or above & 24 & 17.3 \\
Total & 139 & 100.0 \\
& & \\
Educational qualifications & & \\
FSLC & & 16.5 \\
SSCE & 23 & 33.8 \\
NCE/ND/HND & 47 & 38.8 \\
B.Sc./M.Sc./PhD & 54 & 10.8 \\
Total & 15 & 100.0 \\
& 139 & \\
Occupation & & 23.0 \\
Student & & 100.0 \\
Businessman/woman & 37 & \\
Civil/public servant & 53 & \\
Unemployed & 32 & \\
Total & 17 & \\
\hline
\end{tabular}

Source: Field survey (2020)

Table 1 above presents data on respondents' demographic characteristics. It reveals that 79 respondents (56.8 percent) were single, 44 respondents (31.7 percent) were married, while 16 respondents (11.5 percent) were divorced. With respect to age, it was revealed that 60 respondents (43.2 percent) were 18-24 years, 17 respondents (12.2 percent) were 25-31 years, 18 (12.9 percent) were 32-38 years, 20 respondents (14.4 percent) were 39-45 years, while 24 respondents (17.3) were 46 years or above. On educational qualifications, 23 respondents (16.5 percent) had FSLC, 47 respondents (33.8 percent) had SSCE, 54 respondents (38.8 percent) had NCE/ND/HND degree, while 15 respondents (10.8 percent) had B.Sc./M.Sc./PhD degree. With respect to occupation, it was revealed that 37 respondents (26.6 percent) were students, 53 respondents (38.1 percent) were businessmen/women, 32 respondents (23.0) were civil/public servants, while 17 respondents (12.2 percent) were unemployed.

Table 2: Model summary of the effect of packaging attributes on consumer patronage of cosmetics in Calabar Metropolis, Cross River State

\begin{tabular}{|l|r|r|r|r|}
\hline Model & R & R Square & Adjusted R Square & Std. Error of the Estimate \\
\hline 1 & $.613^{a}$ & .447 & .431 & 1.722 \\
\hline
\end{tabular}

Source: Researchers' data from SPSS 
Table 3: ANOVA ${ }^{a}$ of the effect of packaging attributes on consumer patronage of cosmetics in Calabar Metropolis, Cross River State

\begin{tabular}{|ll|r|r|r|r|r|}
\hline Model & & Sum of Squares & Df & Mean Square & F & Sig. \\
\hline 1 & Regression & 242.869 & 3 & 80.956 & 36.417 & $.000^{\mathrm{b}}$ \\
& Residual & 300.124 & 135 & 2.223 & & \\
& Total & 542.993 & 138 & & & \\
\hline
\end{tabular}

Source: Researchers' data from SPSS

Table 4: Coefficients ${ }^{a}$ of the effect of packaging attributes on consumer patronage of cosmetics in Calabar Metropolis, Cross River State

\begin{tabular}{|c|c|c|c|c|c|c|}
\hline \multirow{2}{*}{\multicolumn{2}{|c|}{ Model }} & \multicolumn{2}{|c|}{ Unstandardized Coefficients } & \multirow{2}{*}{$\begin{array}{c}\text { Standardized } \\
\text { Coefficients }\end{array}$} & \multirow[b]{2}{*}{$\mathrm{t}$} & \multirow[b]{2}{*}{ Sig. } \\
\hline & & B & Std. Error & & & \\
\hline \multirow[t]{4}{*}{1} & (Constant) & 5.002 & 1.257 & & 14.978 & .000 \\
\hline & Brand name & .020 & .071 & .221 & 8.280 & .000 \\
\hline & Packaging information & .045 & .075 & .449 & 7.598 & .001 \\
\hline & Design of packaging wrapper & .469 & .072 & .530 & 6.555 & .000 \\
\hline
\end{tabular}

Significant @P $\leq 0.05$, Source: Researchers' data from SPSS

Table 2 presents the model summary of the effect of packaging attributes on consumer patronage of cosmetics in Calabar Metropolis, Cross River State. The "R" column reveals that the relationship between packaging attributes and consumer patronage is 0.613 (that is, $61.3 \%$ ), which indicates a very strong degree of correlation. The $R^{2}$ value $(0.447)$ indicates that up to $44.7 \%$ of the variability in the dependent variable (consumer patronage) can be explained by the independent variable (packaging attributes). The F-test $(36.417, \mathrm{P}<0.05)$ statistic in Table 3 indicates that the overall prediction of the dependent variable by the independent variable is statistically significant; therefore, the regression model provides substantive evidence to conclude that packaging attributes have a significant effect on consumer patronage of cosmetics in Calabar Metropolis, Nigeria.

The results on Table 4 (the coefficients table) revealed that all the three packaging attributes tested (brand name, packaging information and design of packaging wrapper) significantly predicted consumer patronage of cosmetics in Calabar Metropolis, as their $p$-values were less than the error margin of 0.05 , with positive t-test values indicating that the relationship between packaging attributes and consumer patronage is a direct and positive one. Additionally, the standardized beta coefficient column in Table 4 shows the individual contributions of each independent variable to the model. As can be seen in the column, design of packaging wrapper had the highest contribution to the model with a beta coefficient of 0.530 ( 53.0 percent). This is followed by Packaging information, with a beta coefficient of 0.449 (44.9 percent). The least contributor to the model is brand name, with a beta coefficient of 0.221 (22.1 percent). The results of the multiple regression analysis show that the $p$-values (Brand name $=$ 0.000 , Packaging information $=0.001$, and Design of packaging wrapper $=0.000$ ) of all independent variables were less than the error margin of 0.05 , hence we reject all the null hypotheses, accept all alternative hypotheses and conclude that brand name, packaging information and design of packaging wrapper have a significant effect on consumer patronage of cosmetics in Calabar Metropolis, Cross River State.

\section{Conclusion}

The effect of packaging attributes on consumers' patronage has been probed by various researchers for years. Empirical studies have been conducted in various countries in order to provide evidence on how packaging attributes influence consumers' patronage. Like other studies, this research examined packaging attributes and consumer patronage of cosmetics in Calabar Metropolis, Cross River State. Primary data were obtained from respondents using structured questionnaire. The data were analyzed using multiple linear regression with the aid of the Statistical Package for the Social Sciences (SPSS 23). The findings revealed that brand name, packaging information and design of packaging wrapper have a significant effect on consumer patronage of cosmetics in Calabar Metropolis, Cross River State. This implies that the patronage of cosmetics by consumers in Calabar has been significantly increased as a consequence of packaging attributes. Hence, the study concludes that packaging attributes have a significant effect on consumer patronage of cosmetics in Calabar Metropolis, Cross River State.

\section{Recommendations}

The study presents the following recommendations in line with the findings of the study:

1. Manufacturers of cosmetics in Calabar should strive to build strong brand names for their products by maintaining the highest level of product quality in order to enhance consumer patronage. 
2. Adequate product information should be displayed on the packaging of cosmetics to enable consumers to make informed purchase decisions.

3. Manufacturers of cosmetics in Calabar should consistently ensure that attractive designs are displayed on the packaging of their products in order to entice consumers to patronize.

Funding: This research received no external funding

Acknowledgements: The authors acknowledge the scholars whose works are cited and the respondents who completed and returned the questionnaire copies in time. The typist who typed the manuscript is also acknowledge and other contributors, who contributed in one way or the other.

Conflict of Interest: The authors declare no conflict of interest.

\section{References}

[1] Adebisi, S. O. \& Akinruwa, T. E. (2019). Effectiveness of product packaging on customer patronage of Bournvita in Ekiti State. British Journal of Marketing Studies, 7(2), 1-14.

[2] Carter, B. (1991). Ivan Pavlov's Classical conditioning theory: Adaptation for marketing. European Journal of Scientific Research, 122(2), 2631

[3] Ebitu, E. T. (2019). Marketing management and strategy $\left(2^{\text {nd }}\right.$ Ed.). Calabar: University of Calabar Printing Press.

[4] Garrison, E. (2019). Packaging. Retrieved from: https://businessjargons.com/packaging.html

[5] Ghosh, B. (2016). Impact of packaging on consumers' buying behaviour: a case study of Mother Dairy, Kolkata. Journal of Management, 12(1), 63-69

[6] Ibrahim, R., Abdullahi, D. \& Bello, M. (2019). Impact of packaging on consumer buying behavior in Nasarawa State. International Journal of Sciences: Basic and Applied Research, 36(4), 28-46

[7] Imiru, G. A. (2017). The effect of packaging attributes on consumer buying decision behavior in major commercial cities in Ethiopia. International Journal of Marketing Studies, 9(6), 43-54

[8] Ishaku, E. \& Tijani, R. (2013). Impact of packaging on consumer purchase of beverage drinks in Taraba State. African Journal of Business and Communication Technology, 30(12), 50-66

[9] Ismaila, G., Tanko, B. \& Halilu, A. (2017). Effect of product packaging on Nigerian consumers' behaviour in Adamawa State. European Journal of Scientific Research, 27(6), 145-158

[10] Kalpana, R. (2019). Product packaging: Meaning, levels, functions and importance. Retrieved from: https://www.businessmanagementideas.com/packaging/product-packaging-meaning-levels-functions-importance/2271

[11] Kamiah, M. (2017). Meaning, function, types, importance and features of packaging. Retrieved from: https://www.kullabs.com/classes/subjects/units/lessons/notes/note-detail/6767

[12] Keller, K. L. (2009). Choosing brand elements to build brand equity in strategic brand management (3rd Ed.). Delhi: Dorling Kindersley.

[13] Lavidge, R. \& Steiner, H. (1961). A model for predictive measurements of advertising effectiveness. Journal of Marketing, 25(6), 59-62

[14] Mauricio, P. (2015). Product packaging and branding. Retrieved from: https://courses.lumenlearning.com/boundlessbusiness/chapter/product-packaging-and-branding

[15] Mzwella, P. \& Saviour, T. (2018). The impact of packaging elements on consumer buying behaviour of fast-moving consumer goods (FMCGs) during the hyperinflationary and after the dollarization eras in Zimbabwe. Asian Journal of Social Sciences and Management Studies, 4(1), 20-37

[16] Okereocha, C. (2018). Nigeria's beauty products' market worth N500b. Retrieved from: https://thenationonlineng.net/nigerias-beautyproducts-market-worth-n500b

[17] Oladele, P. O., Olowookere, B., Okolugbo, C. N. \& Adegbola, E. A. (2015). Product packaging as a predictive factor of consumer patronage of toothpaste in Ado-Ekiti, Nigeria. British Journal of Marketing Studies, 3(3), $12-28$.

[18] Orji, M. (2014). Packaging attributes and consumer purchase behaviour towards bread products in Abia State. Journal of consumer Research, 16(1), 12-21

[19] Owolabi, J. \& Isaac, P. (2009). Effect of product packaging on consumer buying behaviour towards agro-processed food products in Oyo State. Journal of Business Economics and Management, 8(4), 253-262

[20] Robert, J. L. (2011). Is your packaging an effective communicator? A normative framework for increasing the communicative competence of packaging. Journal of Marketing Communications, 8(3)207-220.

[21] Rundh, B. (2005). The multi-faceted dimension of packaging marketing logistic or marketing tool? British Food Journal, 107(9), 670-684. 